\title{
TRANSFORMATION OF THE NATIONAL CHARACTER IN A.N. OSTROVSKY'S TRANSLATIONS
}

\author{
Irina Budanova \\ Assoc. Prof., Peoples' Friendship University of Russia (RUDN University), RUSSIA, \\ budanova_ib@pfur.ru
}

\begin{abstract}
The article is a comparative study of works of the Russian playwright A.N. Ostrovsky and Italian playwright C. Goldoni.

Particular attention is paid to the analysis of the modification of the category of national character in A.N. Ostrovsky's play Coffee Shop, which is his translation of C. Goldoni's play La bottega del caffè, as a key parameter in the creative work of both playwrights.

The article defines the commonality of Goldoni and Ostrovsky's attitude towards the creation of a national theatre (based on new aesthetics that justifies all genres of comedy subject to its maximum approximation to the truth of life); the reasons for Goldoni's interest in the category of national character; the key problem in reforming the theatre (the lack of the comedy of characters in the native theatre as the most useful genre in terms of the educational mission of theatrical art as well as the lack of real characters drawn from life in the existing repertoire); the linguistic features of the comedy of characters; the Italian national character traits; and also the reasons for Ostrovsky's addressing to Goldoni's work.

Analysing textual changes, it is possible to understand the principle of describing and recreating national characters in translations, which allows us to identify the features of A.N. Ostrovsky's translation manner in relation to Italian dramatic works.

The materials of the article can find practical application in the study of the history of the intercultural dialogue, in academic and special courses on the theory, practice and history of literature and literary translation in higher educational institutions, in studies on the category of national character or linguistic world view as well as in comparative linguistics, comparative cultural or literature studies.
\end{abstract}

Keywords: national character, culture, Russian-Italian cultural ties, playwriting, A.N. Ostrovsky, C. Goldoni, Russia, Italy.

- The reported study was funded by RFBR according to the research project №20-012-00084-

\section{INTRODUCTION}

The internationalisation of many processes developing in modern society stimulates the humanities to revise cultural phenomena that occurred at different time intervals in different countries but that have a common development vector from the standpoint of comparison, i.e. comparative linguistics. This phenomenon is very well reflected in the art of playwriting.

Alexander Nikolayevich Ostrovsky was a Russian playwright, public and theatrical activist, the founder of the national theatre. Recognised as a writer, Ostrovsky has been almost unknown as a translator, although translation occupied an important place in his work and is currently of exceptional interest for literary studies, the theory of literary translation of dramatic works, and the study of his artistic method. The relevance of the 
study is due to the interest of modern philological science in the heritage of world culture, the increased interest of modern literary criticism in matters of receptive poetics, including translation, and the lack of comparative studies on Ostrovsky's translations in relation to the Italian theatre.

World dramatic art has often been a mutually enriching process of sharing discoveries in the field of reproduction of human relations and their interpretation. The theatre encouraged writers, playwrights, actors, and directors to think about the manifestation of national and foreign characters, the development of which was provided by translations. It is the texts of plays that are the sources for identifying and analysing the category of national character.

Modern studies in the field of cultural linguistics and intercultural communication indicate that there is a direct dependence of national character traits, and their reflection in language and linguistic consciousness, on the type of personal culture.

The concept of 'national character' is ambiguous. This category is studied in various sciences: cultural studies, ethnology, psychology, political science, linguistics, and some other related disciplines.

The main difficulty in national character studies is identifying precisely national types against the background of universal (independent of ethnicity) psychotypes as well as fixed ideas - stereotypes about typical national features.

National character studies were conducted by such researchers as A. Wierzbicka ("Semantics, Culture and Cognition: Universal human concepts in culture-specific configurations", 1992, "Cross-Cultural Pragmatics: The semantics of human interaction", 1991), S. G. Ter-Minasova ("Language and Intercultural Communication, 2000), W. Wundt, M. Lazarus, H. Steinthal, A. Kardiner, R. Benedict, M. Mead, R. Merton, R. Lipton and others.

Of greatest interest are works at the intersection of linguistics, cultural studies and psychology, exploring national characters through the connection of language and culture as key elements of the linguistic world view. In such works, the main research method is a comparative analysis of texts written in different languages. It is the linguistic analysis that makes it possible to find and show the various attitudes embedded in the texts and, therefore, to determine the national character traits of various ethnic groups.

'National character' is a concept that causes a lot of controversy, due to which it has not received an unambiguous interpretation as yet. In this paper, following the recognised researcher of national culture and social psychology, N. Dzhandildin, who defined 'national character' as "a set of specific psychological features that have become more or less characteristic of one or another socio-ethnic community in specific historical, economic, cultural, and natural conditions of its development" (Dzhandildin, 1971, p. 122), we will understand 'national character' as a set of stable features of world perception, such as expressions of emotions, motivations, value orientations, traditions, interests, rituals and responses.

We set ourselves the task of testing the hypothesis that in the translation process due to the adjustment of the text necessary to adapt it to the Russian reader (Russian language consciousness), a modification of the category of national character occurs, i.e. the original image presented in the source text is changed in the translated one.

\section{To test the hypothesis, we needed to solve the following questions:}

- To describe the commonality of C. Goldoni's and A.N. Ostrovsky's attitudes towards the creation of a national theatre;

- To determine the reasons for C. Goldoni's interest in the category of national character;

- To identify the Italian national character traits; and

- To highlight the linguistic characteristics of the comedy of characters.

\subsection{Goldoni and Ostrovsky: Attitudes towards the Creation of a National Theatre}

The great Venetian Carlo Goldoni (1707-1796) and the Russian playwright A.N. Ostrovsky (1823-1886) entered the history of world culture as reformers and creators of their national theatres. The common task of reforming the scene and the responsibility assumed for its implementation allows researchers to identify parallels in the creative work of both playwrights. A.I. Zhuravleva notes that Goldoni is the closest of the European reformers to Ostrovsky in terms of his tasks. However, the reform paths of the Italian and Russian playwrights went in different directions, because "Goldoni led the Italian scene from the tradition of the folk theatre of character 'types', that were kind of minted and already in his time hardened in commedia dell'arte, 
to the demonstration of national character and lifestyle expressed in the diversity of faces that life itself creates. $<\ldots>$ he took decisive steps on the way from the theatre mask to the face" (Zhuravleva, 1986, p. 6), whereas Ostrovsky's reform "consisted in the fact that he had merged the Russian theatre with national roots, based on his own popular comedy, which mastered the types and masks that had existed in everyday life and culture of those strata where national forms of household had been preserved" (Zhuravleva, 1986, p. 7). Goldoni took folk material as the basis and built on it something new, more modern, but at the same time national, reflecting the folk types of commedia dell'arte, although more unifying, whereas Ostrovsky returned from his contemporary theatre, which was under Western European influence and far from common spectators, to the folk roots.

\subsection{The Key Problem in Reforming the Theatre: the Comedy of Characters}

When Goldoni was 17 years old, one old comedy fell into his hands. It was Machiavelli's La Mandragola [The Mandrake]. The book, which the future playwright read ten times, impressed him very much: "Of course, this play captivated me not with its free language or its seductive intrigue. On the contrary, I was outraged with its obscenity, and that the abuse of confession is a terrible sin before God and people, I myself knew well. But this was the first comedy of characters (emphasis added by us), which caught my eye, and it enchanted me. I wanted the Italian writers to continue to compose plays in the same way, but only more decent and presentable, and characters 'drawn from life' to replace romantic intrigues. But only Molière had the honour to ennoble the comic scene and make it useful, putting vices and oddities in the pillory and redemption. At that time, I did not know this great man, as I did not read in French. I decided to learn this language later, but for now I have acquired the habit of taking a closer look at people and not missing unusual characters" (Goldoni, V. 3, pp. 86-87).

Thus, under the influence of Machiavelli's play, Goldoni defines his aspiration, which subsequently led him to the reform of Italian comedy. The main aesthetic line is formed in the memory, which determines the artistic originality of the Italian playwright' works - characters created by the principle of the greatest similarity to life, noticed in real everyday situations.

\section{METHODS}

Using the methods of analysis and observation, based on a description of the actions of the characters, their behaviour, reactions, and motivations in the text of the play, we can identify the following Italian national character traits:

1. Easy attitude to life

2. Venturesomeness

3. Resourcefulness

4. Desire to win the dispute

5. Care for simple joys of life

6. Commitment to moderate life

7. Honesty

8. Didacticism 


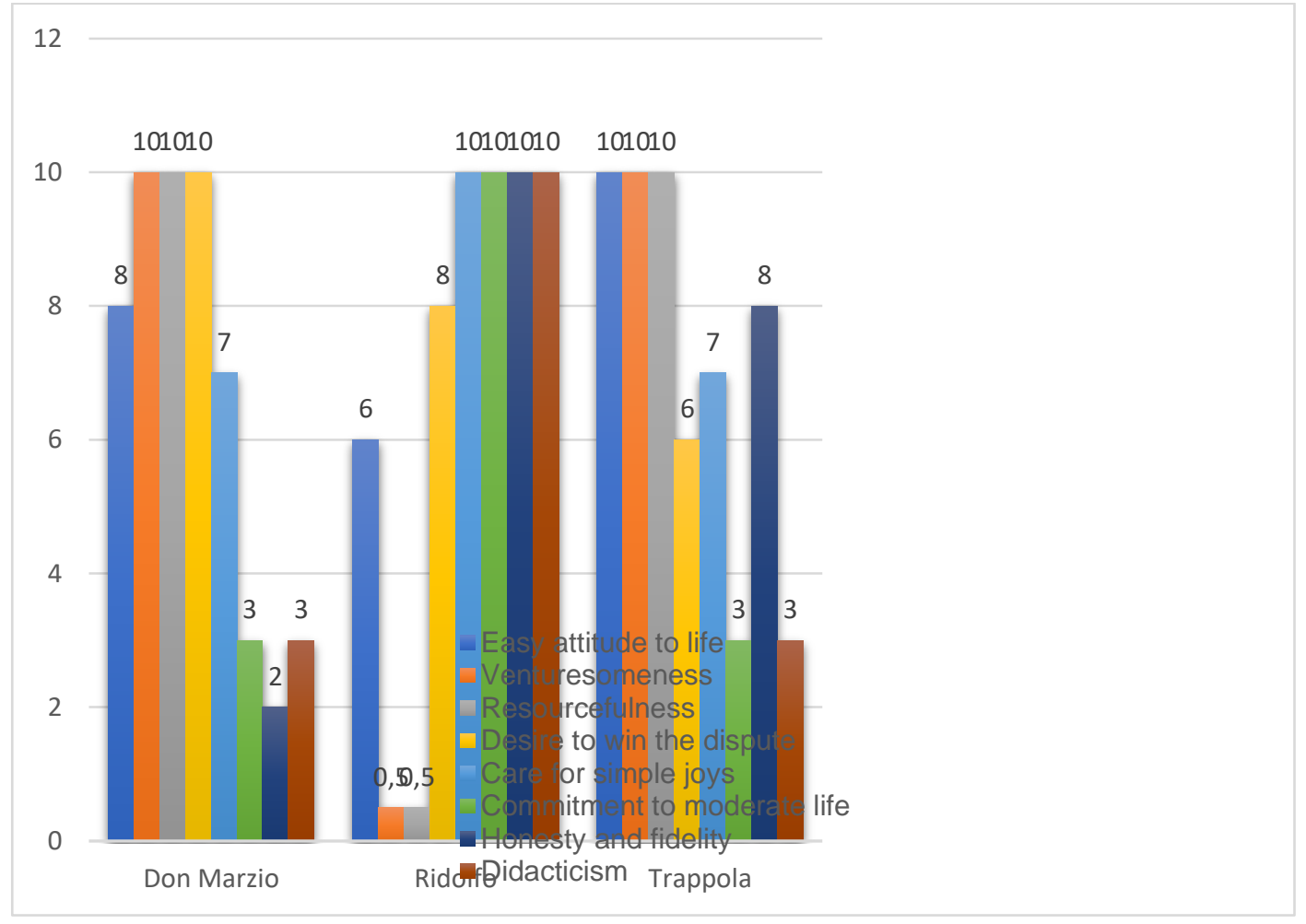

Figure 1: Italian National Character Traits

Some traits, for example, "venturesomeness" and "resourcefulness" are opposed to "honesty": the presence of opposites, especially at the level of characters, is a necessary condition for the conflict in a dramatic work. Goldoni explained the brilliant success of his comedy exactly by this: "The combination of opposing characters could not help but please" (V. 4, p. 67), which, undoubtedly, was interesting to A.N. Ostrovsky. It was character drawing that was of particular importance to A.N. Ostrovsky. He himself, in his article From the Translator, notes that Don Marzio is an example of Goldoni's art in portraying characters: "In this play, long and overflowing with bare morality (which I reduced as much as possible), the type of Don Marzio shows that Goldoni was a great artist in drawing characters (emphasis is added by us)" (Ostrovsky, V. 10, p. 108).

Dialogues play a special role in the comedies of Goldoni and Ostrovsky - they are exactly embodied actions. Of real interest is Ostrovsky's work on the language of characters. The diagram in Table 1 shows how the above-mentioned national character traits are manifested by these heroes (the maximum manifestation of the trait is indicated by 10 points).

Note that the Items 1-4 are characteristic of Don Marzio and Trappola (Ridolfo's servant) as well as other male adventurous characters: Count Leandro, Eugenio and Pandolfo; Items 5-8 are characteristic of Ridolfo, who personifies the bourgeois ideal of a quiet life. The female characters in this play do not show vivid national traits. Such traits as 'easy attitude to life' and 'care for simple joys' are all Italian, regardless of the character's positivity or negativity.

\section{RESULTS}

The performed analysis of this material allows us to conclude about the causes of these changes. Stylistically neutral words were replaced by variants that are marked in dictionaries as 'colloquial' or 'vulgar' (for example, the descriptive phrase "che non tace mai, e che sempre vuole aver ragione" [who is not silent and who always wants to be right]) was replaced by Ostrovsky with the short colloquial "chatterer", and lengthy expatiations were removed, since they did not carry any semantic charge but only overloaded the action. For example, Ridolfo's reflection on the causes and results of his actions was removed: "Io non so come si possa dare al mondo gente di così poco giudizio! II signor Eugenio vuole andare in rovina, si vuol precipitare per forza. A me, che ho fatto tanto per lui, che vede con che cuore, con che amore lo tratto, corrisponde cosi? Mi burla, mi fa degli scherzi? Basta: quel che ho fatto l'ho fatto per bene, e del bene non mi pentiro mai". (Literal translation: "I do not know how people of such a small mind can exist in the world! Signor Eugenio wants to go into ruin, wants to fall even more. And to me, who has done so much for him, 
who sees with what heart, with what love I treat him, he answer like that? He laughs and mocks at me? Enough! What I did, I did for good, and I will never repent of good").

Don Marzio is a Neapolitan nobleman, whose Italian national character is most clearly manifested - he is smart, cheerful, adventurous, quirky, comes out winning from all situations. In the translation, Ostrovsky preserves the fast rhythm of his speech and conveys his wit. For example, in one of the dialogues, a dispute arose over what time of day it was. Don Marzio claimed to be sixteen hours, although his watch showed fourteen, which was true. Don Marzio is in the position of a dodgy time-server who says only what is beneficial to him, even if this is not true, and he himself believes in his own words, but is not responsible for them and easily refuses what he said, accusing his interlocutor of misunderstanding.

The owner of the coffee shop, Ridolfo, was drawn by Goldoni more emotionally: this was indicated by remarks that characterise the intonation (mocking, contemptuous, etc.). Having deleted the remarks in the translation, Ostrovsky made the hero pronounce the phrase "They sent a bad watch" with a more serious tone, due to which the comic effect of the dialogue is enhanced. Pronouncing "con sdegno" ("with indignation/resentment/contempt") does not quite fit Ridolfo's calm character. Such an expression of feelings is more consistent with melodramatic pathos than with the moderate ideal of worldly virtue.

Trappola is partly a characteristic double of Don Marzio, but Don Marzio does not recognise his vices, while Trappola honestly recognises them.

\section{DISCUSSION}

In this paper we described the commonality of Goldoni and Ostrovsky's attitude towards the creation of a national theatre, based on new aesthetics that justified all genres of comedy subject to maximum approximation to the truth of life; defined the reasons for $\mathbf{C}$. Goldoni's interest in the category of national character; the key problem in the reform of the theatre - (the lack of the comedy of characters in the native theatre as the most useful genre in terms of the educational mission of theatrical art as well as the lack of real images drawn from life in the existing repertoire; highlighted the linguistic features of the comedy of characters, such as: numerous metaphorical, figurative expressions and phraseological units, syntactic structures in dialogues characterised by repetitions creating a certain dynamics in a dialogue; revealed the Italian national character traits: easy attitude to life, venturesomeness, resourcefulness, desire to win the dispute, care for simple joys of life, commitment to moderate life, honesty, and didacticism.

Goldoni's Theatre, combining the national masks with an interest in character, was close to Ostrovsky's Theatre. The problem of national character is perceived by Ostrovsky as a key one in Goldoni's aesthetics. Goldoni's creative work, in particular, his 'Venetian plays', charged with the energy of creating national life and permeated with life-affirming pathos in relation to man, acquires an important moral, philosophical and aesthetic meaning for Ostrovsky.

It is fundamentally important for the linguistic system of comedy to create a commonality of the whole artistic language, which is based on folk poetic speech. Another distinctive feature of the comedy language is the type of syntactic structure in dialogues, characterised by repetitions and creating musicality in a dialogue. In a play, the national character is embodied through language.

The revealed conceptual changes that occurred due to the replacement of the lexical unit 'curioso' with 'jester' indicate the reinterpretation and evolution of images that occurred with the world drama in A.N. Ostrovsky's work.

\section{REFERENCE LIST}

Volgin D. V. Years of A.N. Ostrovky (as remembered by N.Ye. Komissarova). Privolzhskaya Pravda, 1936, No. 136 ,

Goldoni C. Memorie per l'istoria della sua vita e del suo teatro. In 4 volumes. Transl., intr., and notes by S.S. Mokulsky. Moscow, 1997, V. 3, 592 p. 816 p.

Dahl V.I. Explanatory Dictionary of the Living Great Russian Language. In 4 volumes. Moscow: M.O. Volf Printing house, 1882, V. 4, 710 p.

Dzhandildin N. D. The Nature of National Psychology. Alma-Ata, 1971. 304 p. 
Zhuravleva A.I., V.N. Nekrasov. A.N. Ostrovsky's Theatre. Moscow: Prosveshchenie Publ., 1986. 205 p. Italian-Russian Dictionary [Electronic resource]. ABBYY Lingvo, 1996-2016. URL: http://www.lingvo.ru/ (accessed: 20.06.2018).

Kovalev V.F. Italian-Russian Dictionary [Electronic resource]. V. F. Kovalev. Zanichelli, 2001. 1 CD-ROM. Literary Encyclopedia of Terms and Concepts. Gasparov M.L. (Ed.) Moscow: NPK Intelvak, 2001. 870 p. Mikhelson M. I. Mikhelson's Big Explanatory Phraseological Dictionary [Electronic resource]. In 3 volumes. Moscow : 2004. 1 CD-ROM. 216 thous. Rus. words, 44 thous foreign words.

Ostrovsky A.N. Complete works. In 16 volumes. Moscow: Gospolitizdat, 1949-1953, V. 1-16,

Ostrovsky A.N. Complete works. In 12 volumes. A.N. Ostrovsky. Moscow: Iskusstvo, 1973-1979. V. 1-12,

Ter-Minasova S. G. Language and Intercultural Communication. Moscow: Slovo Publ., 2000. 624 p.

Khlodovsky R. I. Italian literature. History of world literature. In 9 volumes. Moscow, 1988, V. 5, pp. 191-193.

Stein A. L. Ostrovsky and World Drama. A.N. Ostrovsky: New materials and research. V.G. Bazanov [et al.]. Moscow, 1974, V. 88, Book 2, pp. 43-74.

Carbaugh D. Cultural and Intercultural Contact. Lawrence Erlbaum Associates, 1990. 464 p.

Inkeles A. National Character. A Psycho-Social Perspective. New York, 1997. 405 p.

Ferrazzi M. Commedie e comici dell'arte italiani alla corte russa (1731-1738). M. Ferrazzi. Roma: Bulzoni, 2000. 339 p.

Folena G. L'Esperienza linguistica di Carlo Goldoni. Atti di Convegno Internazionale di Studi Goldoniani. Venezia, vol. I, pp. 143-191.

Spezzani P. Dalla commedia dell'arte a Goldoni. Studi linguistici, Padova, Esedra, 1997. 456 p.

Wierzbicka A. Cross-cultural pragmatics: The semantics of human interaction, - Mouton de Gruyter, 1991. $502 \mathrm{p}$.

Wierzbicka A. Semantics, Culture and Cognition: Universal human concepts in culture-specific configurations. Oxford University Press, 1992. 496 p.

The reported study was funded by RFBR according to the research project №20-012-00084 